\title{
Disciplinary discourses of globalization in the horizon of lack of meaning: "challenge" and the search for an "response"
}

\author{
Leonid Lomako, Konstantin Maltsev and Anna Maltseva* \\ Belgorod State Technological University named after V.G. Shukhov, Belgorod, Russia
}

\begin{abstract}
The overlapping disciplinary discourses of globalization are built in the perspective of the absence of its concept; the concept presupposes the disclosure of meaning, that is, a philosophical interpretation. The representation of the globalization of the form of modernity actualizes its philosophical understanding and sets the perspective for defining its concept; concepts of the "third era of liberation" I.G. Fichte, "the era of nihilism" F. Nietzsche and M. Heidegger's "closing period of modern times" are presented as the horizon of the philosophical interpretation of globalization as planetarism, the essential (conceptual) features of which are "destruction of space" as the removal of boundaries and "compression of time" to total modernity, provided by technology as the arche of modernity. In a metaphysical concept, there is a combination of the real and the actual, which for the new time is essentially subjective; the new European subject and the idea of technology are one essence and there is a beginning from which modernity unfolds and is interpreted, which remains for modernity itself both "unnecessary" and "impossible" (M. Heidegger). The article demonstrates the impossibility of the concept of globalization for the dominant view of modernity in the economic paradigm (J. Agamben) and the essential non-reality of Heidegger's concept of planetarism for modern disciplinarily arranged science. It is concluded that the real challenge is the impossibility of comprehension with the absolute exclusion of the possibility of a response.
\end{abstract}

\section{Introduction}

Since the early 2000s, when the word "globalization" has become firmly established in the vocabulary of the social and political sciences, there are more and more reasonable doubts that this is one of those frequent cases when the "signified" is devoid of meaning. The first to express this was Z. Bauman: "Globalization" is on everyone's lips today; a buzzword that quickly turns into a slogan, a spell, a kind of key that can open the door to any existing and future riddles. All buzzwords, as a rule, face the same fate: the more they claim to clarify something, the less clear their meaning becomes. The more they crowd out orthodox truths, the faster they themselves turn into indisputable canons. Attempts to understand the phenomenon with the help of hypotheses disappear from the field of vision” [1]. Further, M.

\footnotetext{
* Corresponding author: pavic69@mail.ru
} 
Mann echoes him: "Most of the discussions on the topic of globalization are not particularly interesting. The process of globalization itself is unremarkable, apart from its scale" [2]. M. Mann is skeptical about modern globalization theories and their creators, calling the first "globuda", and the second - hyperglobalizers and arguing that they only expanded the geography of the previous theoretical constructions. That is, we can assume that the presence of a multitude of overlapping discourses of globalization in various scientific disciplines is somehow combined with the absence of the concept of globalization - the purpose of this article is to demonstrate the necessity of this situation.

\section{Study Methods}

The difference between understanding and explanation explained by German philosophy (W. Dilthey, G. Rickert, for example) can not be held either by separate independent scientific disciplines, or in the form of "interdisciplinarity", but there is the exclusive prerogative of philosophy; only a philosophical concept is capable of "working with meanings" - that is, philosophical interpretation is the only way to reveal the meaning of globalization, if any. However, M. Heidegger's assertion that "the simplest philosophical cognition in the era of the completed modern time is the knowledge that and why philosophy shall have become impossible and for this era remains unnecessary" [3], reveals a place for the question of the possibility/impossibility of the concept globalization, which in any case cannot be thought of other than as a specific form of what is called modernity, to the essence of which Heidegger refers, among other things, to the "impossibility of philosophy". Therefore, "the question can be posed": the "impossibility" and "uselessness" of the philosophical interpretation of modernity one of the consequences has the necessary and demonstrative absence of the "concept of globalization" and it is necessary to find out what exactly in what is called "modernity" excludes the possibility of it philosophical interpretation (and, according to M. Heidegger, philosophy as such). Obviously, such a question itself belongs to the field of "impossible philosophy", that is, it cannot be "solved", but only interpreted; the result of the interpretation will be, among other things, an understanding of why globalization, as one of the forms in which modernity becomes valid, does not make sense and, therefore, cannot have a clue.

\section{Study Results}

The philosophical interpretation of the meaning of modernity is the building of the horizon of its understanding; its (horizon) constitutive is the decision, - three philosophical concepts of modernity: "the era of liberation" from "reasonable instinct" and "reason in general", freedom from the "commanding authority" I.G. Fichte; "Era of Nihilism" F. Nietzsche; M. Heidegger's "concluding period of new time", - are designed in the perspective of solutions specific to the new European metaphysics of the subjective (Kantian) method of combining the real and the actual, placing a rational subject in the center in various ways: defining "rationality" Fichte, "superman" F. Nietzsche and M. Heidegger's "New European subject",

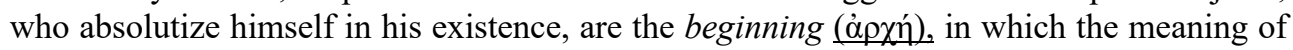
modernity is acquired and from which its philosophical interpretation is implemented. In Fichte (and Hegel) and Nietzsche, according to Heidegger, the modern European metaphysics receives its "completion", which means that the modern European history also ends with respect to its meaning; its subsequent "reality" is meaningless: Heidegger discusses the "inability to die" and the "infinite duration" of the completed modern European history, the senseless and accelerating movement of which "nowhere" is what is called "modernity"; globalization, or, as Heidegger calls it, "planetarism" is a necessary form of such a 
movement. The apparent difference between Fichte's and Nietzsche's, on the one hand, and Heidegger's understanding of modernity is that Heidegger insists that modernity cannot end ("die"), much less, as Fichte believed, "move" to something "different" (in Fichte - to the "fourth" and "fifth" epochs of "reasonable science" and "intelligent art"), - "the final period of new time" is the "era" of a new European subject, self-asserting in its existence, the interpretation of the "essence" of which gives an understanding of modernity [3; 4].

Modernity is constituted subjectively: "The subjective character of a person - as a modern European - is the deepest historical force" [3], - "The era, which strengthens its essence the more, the more it thinks only about what it does. But "it does" only what the fullness of subjectivity shall do - self-preservation in the absence of comprehension - possibly up to self-destruction" [3]. Strictly speaking, the self- evident assurance of "Western thought" that "individuals exist in themselves and by themselves" (Calhoun) is based on a liberal interpretation of the Kantian idea of an autonomous subject freely self-determined in accordance with internal law. It is enough to "close the transcendental perspective" for the subject to become "its own and only space and time" [3], that is, the person "knows that he/she is a human being" and aims to ensure his/her humanity in its present given: "A person with everything he/she has it at his/her disposal and his/her own brings all human community and inherited humanity into the underlying basis of all assessments and plans and implementations and makes it possible to lay the basis for measure and purpose and planning as an area" [3]. Only now a person can set himself/herself in motion "from within" - and in such a way that the question of where it is rolling (rollt) loses all meaning for the rolling person; the subject itself (Subjektum) is its own and only space and its own time" [3]. This "rotation within oneself" is the essence of the new time: innovation is a machination, constant "change/reform" means that "the course of the history of the New time, despite the growing speed, slows down more and more, stagnation becomes more and more persistent, and the longevity of this jumble of all possibilities subjectivism - all the more true. Only when we open up and see in this domination the Subjektum, how he/she brings himself/herself as the core of existence" [3].

Reality is given to the subject in his/her view, and the person is completely determined not to rely on "chance" anymore, but to include everything "without reserve" in the planning calculation of the mind" [3]: "A person knows that he/she is a person when he/she is serious about all this possession, profits from it and no longer tolerates anything and justifies any impact by success and everywhere asserts itself as this Subjektum" [3]. "The closure of the transcendent," that is, no questioning, ends with the triumph of "ensuring life (Lebenssicherung)" [3], that is, - security policy provides a way of existence for the new European subject: "ensuring life", "questionlessness" - this is security, and it is comprehended from the very essence of subjectivity. Safety, that is, calculation and planning, calculability of existence, is the way in which the subject guarantees his/her reality, with a predetermined outcome/goal: "New European person aims to preserve his/her essence to one day become a part of the machine and in the service of ensuring the expediency and calculation of his/her work, to find his/her easy security, his/her motives and his/her lust. This introduction into the machine essence is nothing essentially other than the mere use of "technical" possibilities; here, there is an extreme likening of the essence of man to the calculating (Rechenhaftigkeit) of being. It is with the help of all this that spirit (i.e. rationality and prudence of animality) and comes to its highest power" [3].

Therefore, "the triumph of the new European subject" as the essence of the final period of modern times, means that the principle of its "own form" is $\tau \dot{\varepsilon} \chi v \eta$ as the production of life. The philosophical "horizon of modernity" (history) differs from the scientific (historiographical): in philosophy, modernity is interpreted as growth from the beginning (Greek $\alpha \rho \chi \eta)$ ), "unfolding" (Hegel) of the beginning until the coincidence of its real and actual; in this sense, modernity is a new time (the beginning was laid by Descartes in the 
"self-reliance of the subject," in whose representation reality is attested), the "final period" of which we have been experiencing, according to Heidegger, since 1890. The essence of modernity includes: technology, as its principle (and as the principle of everything modern); the subject as a place of realization of the domination of beings in the form of objectivity as "representation of the given" and evidence as reliability (Heidegger: "Extreme" subjectivism" is achieved when the publicity of planetary infinity is ensured, that is, arbitrariness" [4]); infinity as infinite duration and "inability to die" - the absence of a place and possibility of a solution in modernity - what has been said can be combined as follows: infinite and homogeneous (capital as "the universal logic of the social": S. Zizek with reference to K. Marx [5]), the duration of the "same" existing through the "interaction" of technology and the new European subject ("historiographic man"), which are one and the same.

Modernity is devoid of self-awareness; all the more verbose is its self-articulation, including in the kaleidoscopic variability of "innovative scientific theories" (the endless transformation of the configuration of the discourses of globalization [6], with the indispensable dominance of the economic [7] and attempts to limit the "economic monocausality" by politicizations (W. Beck) and cultural studies [8] and the historicization of globalization [9]), which, as Heidegger argues, are always new, while nothing new can be; modern discourses of globalization are typical examples of "innovations", the essence of which has become clear even to sociologists, who fundamentally exclude the legitimacy of a philosophical interpretation: Z. Bauman, M. Mann (another evidence that the final period of modern times has come).

\section{Discussion of Results}

So, the philosophical concept of globalization is what Heidegger called "planetarism"; but "existential-historical thinking," as Heidegger himself argued, is something fundamentally alien to modernity: he insists on the need to "leap behind" - such philosophical comprehension is the prerogative of "loners", and "silence" rather than "enunciation" is its essence. However, Heidegger's concept of "planetarism" has advantages that are undeniable from the point of view of science: firstly, back in the 30s of the twentieth century, Heidegger was able to determine the "characteristic features" of what later came to be called globalization, that is, the forecast in the horizon of historical thinking proved to be accurate; secondly, globalization, represented through the concept of "planetarism", exclusively unites the real and the actual, as a "metaphysical concept" (K. Schmitt [10]).

Common to all modern disciplinary discourses of globalization is the assertion that globalization is a state of modernity in which the "destruction of space" becomes reality as the removal of boundaries and "compression of time" to total modernity provided by technology (the development of modern technologies that totally transform life). It is this, as a necessity, defined by Heidegger as the characteristic features of the concluding period of modern times: homogeneous, borderless space (the border is always a sovereign political decision, for which there is no place in modernity) and infinite duration outside of history and without the possibility of "completion" - to understand the indicated necessity is the task of philosophical interpretation, concepts; its (necessary) presentation was the subject of our consideration.

The named essential features of globalization, which form the content of Heidegger's concept of planetarism, determine the specific appearance of globalization as a form of modernity, and they are also defined and interpreted by $\mathrm{M}$. Heidegger.

The absence of the possibility of "self-knowledge" and, thus, "falling out of history" "historiographic recalculation" of the past and calculating planning of the future from the infinitely lasting present, the machinative essence of which means "historiographically 
conceivable definition of the same everywhere - the abandonment that encompasses the entire Earth the being of beings" [4], that is, "the identity and equalization of humanity in the way of realizing life order, despite the apparent difference in the origin and significance of "cultures" and national (volklich) characteristics (Bestände) (Japan, America, Europe), have their own essential the basis is that power itself, to the extent that it has reached absolute authority, requires the same and uniformity of increasingly simpler means. Any power seeks to expand and at the same time runs into another in the same machinations. This essential sameness is the basis of the historiographically established totality and absoluteness of the essence of power (Machtwesens)" [4]. Differences are welcomed precisely insofar as and because they are not essential; an arbitrary combination of "lifestyles" not only does not hinder, but is a necessary condition for total homogenization; in the same cases when the "difference" is "not reducible" to the "free choice" of the autonomous individual (political "projection" of the new European subject), it is declared "fundamentalist" and is subject to "elimination". In the "world-wide historical problem of mass order, first of all, the mass character of mankind is confirmed, and technology is assigned with the absolute role of an authoritative type of knowledge (news, i $\sigma \tau$ -

Fundamental "fragmentariness" is also a necessary condition for homogeneity and totality, - essential meaninglessness (Heidegger repeatedly asserts that "meaning is not needed" and is impossible for modernity, the present subject is no longer "bound" by meaning and is free in the production of simulacra: "New European person is more does not need symbols-semantic images (Sinnbild), not because he/she denies meaning, but because he/she masters it as an authorization of the person himself/herself to become the calculating center of all arrangements of any machination for existence as a whole" [3]) is called idiocy: planetarism is precisely idiocy, the final triumph of which is the goal of the "security policy". Heidegger writes: "Planetarism corresponds to idiocy. - This word here does not imply the psychiatric concept of powerlessness of spirit and soul. It (idiocy) is thought of as beinghistorically and presupposes $\tilde{i} \delta 10 v$ - the special (das Eigene), in which today's person finds himself/herself within the framework of the mass order. This particular is the sameness, in which both the other and each, in which "people" are and alternately confirm themselves" [4]. Idiocy means that "the sameness is transferred to what belongs to everyone; for example, the authority of the "Illustrated Magazine"; the obligatory address of the radio (des gänzlich manmäßigen Anspruches des Rundfunks), where the "anonymous" broadcasts, although at any, even the most insignificant, "concert" the name and surname of each violinist and trumpeter is announced. People everywhere find themselves in the special, which nevertheless belongs to everyone" [4]. Idiocy "is an important limitation on the world, that is, planetary level. This is only possible in the manner of idiocy. This limitation includes giving up all comprehension, so that denial is not known as denial, as little as the ability to comprehend. Idiocy is, therefore, not the prerogative of, say, "idiots" (that is, people with disabilities). On the contrary: the unconditional sneakiness and resourcefulness and dexterity of a technically historiographic person belongs to idiocy. Only a planetary person can be idiotic, and an idiotic person must be planetary" [4].

Finally, planetarism, like every "radical concept" (like a myth), has a name: "The true initiator of the unity of planetarism and idiocy, but also a truly worthy successor to them, is Americanism - perhaps the hollowest figure of "historiographic "historylessness" [4]. The alternative between "globalization" and "Westernization" discussed for some time is completely resolved in the theory of empire: the "American empire" (D. Lal), as well as the "transnational state" (W. Beck [11]) fully combine the universal political order and "glocalities"; the latter can be interpreted as a "democratic triumph of diversity in unity", but also as a "ghetto" (Z. Bauman), the necessity of which for the very existence of total order can easily be seen (from a certain "point of view"). 
Among the "tools" that ensure the reality of globalization, one can also distinguish those for which the status of "objectivity" is assigned (first of all - "economic", discovered not at all by the theorists of modern globalization, but also, for example, by K. Marx or K. Schmitt), and those that are presented as "political" and use of which requires the deliberate efforts of "actors". In recent years, two such tools have attracted particular attention of researchers: first, education (education as a tool for "sustainable development") [12; 13] and, secondly, digitalization. The task of education is "the formation of human capital" $[14 ; 15]$ and even its "counting" and "testing" according to various "scales" [16; 17] (sometimes disguised by arguments about "creativity" and "gender freedom" [18]): readiness and suitability to "fit into the machine" (of course, it means to be "to the end" defined by the "idea of technology", that is, to integrate into modernity). "Digitalization", which Heidegger also first spoke about in the 30s of the twentieth century as an essential characteristic of modernity and the "last man" ("historiographic animal"): "What kind of intoxication will the growing mania for numbers (Zahlen-Rausch) eventually degenerate into?" [4], - there is a necessary method of total homogenization $[19 ; 20 ; 21]$ as the essence of the end of the new time, that is, the "era of planetarism".

Let us note in conclusion that Heidegger's concept of planetarism includes both Fichte's definition of the "third era" ("the era of selfishness and freedom from the authority of reason": "The era of absolute indifference to all truth and complete licentiousness, not relying on any guidance" [22]), and Nietzsche's understanding of modernity as an "era of nihilism" ("Nihilism is not where being as a machination enters into its unconditional power and settles in it, but where, referring to the tested "ideals" and "cultural values" (as deprived of impact of the goal), hold on to the randomness of the inherited situation" [3]).

\section{Conclusions}

Challenge and response presuppose the disclosure of the area of the existential, that is, the political solution. Economic, social, political "problems" in themselves are never a challenge, but presuppose effective management ("risk management"), - in the economic paradigm (J. Agamben [23]) politics becomes management. M. Weber was the first to point out that it is in modern times that government management may not fundamentally differ from enterprise management; K Schmitt [24] pointed out that, although any "problem" can become political, the principle of liberal metaphysics is the exclusion of the political as such. Modernity, as represented in the economic paradigm, has become evident to the disciplinarily arranged modern science; the disciplinary discourses of globalization are essentially determined by this obviousness (which does not in the least call into question their instrumental suitability for governance), a sovereign political decision is absolutely excluded by the principle of the "rule of law" (the Schmitt and Kelsen dispute [25]). The philosophical interpretation of what is called "globalization" and its representation in the "metaphysical concept" of planetarism make it possible to assert that the real challenge is the meaninglessness of modernity as "the final period of modern times"; however, the response to this challenge is essentially impossible: in reality, planetarism does not have a place for a solution, and the possibility for someone who can decide is excluded (Heidegger in this connection spoke of "the meeting place of man and God", which is no longer possible). Liberal politics as an endless discussion and "management of problems" through reaching compromises on the basis of an institutionally protected "liberal consensus" (now - as a "policy of values"), according to a number of authors (both "left" and "right"), is In essence, an endless ("internal" and "just") war as a "police operation" [26], "its own form" of challenge, which does not imply a response. 


\section{References}

1. Z. Bauman, Globalizatsiya. Posledstviya dlya cheloveka i obshchestva (2004)

2. M. Mann, Istochniki sotsial'noy vlasti v 4 t. T. 4: Globalizatsii, 1945-2011 gody (2018)

3. M. Khaydegger, Razmyshleniya VII-XI (Chernyye tetradi 1938-1939) (2018)

4. M. Khaydegger, Razmyshleniya KHII-XV (Chernyye tetradi 1939-1941) (2020)

5. S. Zhizhek, O nasilii (2010)

6. I. Alami, A. D. Dixon, E. Mawdsley, State Capitalism and the New Global D/development Regime, Antipode, 53(5), 1294-1318 (2021). Access mode: http://doi.org/10.1111/anti.12725

7. S. Knauss, The myth of the global middle class, globalisation's fallback success story, Canadian Journal of Development Studies, 40(2), 182-200 (2019). Access mode: http://doi.org/10.1080/02255189.2019.1520692

8. D. Conversi, The Limits of Cultural Globalisation? Journal of Critical Globalisation Studies, 1(3), 36-59 (2010)

9. H. H. Khondker, Eurasian globalization: past and present, Globalizations, 18(5), 707719 (2021). Access mode: http://doi.org/10.1080/14747731.2020.1842085

10. K. Shmitt, Politicheskaya teologiya, Ponyatiye politicheskogo, 5-59 (2016)

11. A. Blok, S. Selchow, Special theme introduction: methodological cosmopolitanism across the socio-cultural sciences, Global Networks: A Journal of Transnational Affairs, 20(3), 489-499 (2020). Access mode: http://doi.org/10.1111/glob.12292

12. K. Maltsev, A. Alaverdyan, A. Maltseva, National and State Classical University in a Globalizing Modernity, E3S Web of Conferences 295, 05004 (2021). Access mode: http://doi.org/10.1051/e3sconf/202129505004

13. K. Maltsev, L. Binkovskaya, A. Maltseva, Representing "University Education" in the Horizon of the Concept of Sustainable Development and Security Discourse, E3S Web of Conferences 295, 05003 (2021). Access mode: http://doi.org/10.1051/e3sconf/202129505003

14. R. Eckardt, A. Crocker, C. Tsai, Clarifying and empirically assessing the concept of human capital resource emergence, International Journal of Human Resource Management, 32(2), 279-306 (2021). Access mode: http://doi.org/10.1080/09585192.2020.1800784

15. K. G. Mal'tsev, A. V. Mal'tseva, «Chelovecheskiy kapital» kak kontsept biopolitiki: opyt filosofskogo istolkovaniya, Izvestiya yugo-zapadnogo gosudarstvennogo universiteta, Seriya: ekonomika. Sotsiologiya. Menedzhment, 10(5), 242-252 (2020)

16. S. Jones, Testing the Technology of Human Capital Production: A General-to-Restricted Framework, Oxford Bulletin of Economics and Statistics, 82(6), 1429-1455 (2021). Access mode: http://doi.org/10.1111/obes.12374

17. J. de Frutos-Belizón, F. Martín-Alcázar, G. Sánchez-Gardey, Conceptualizing academic intellectual capital: definition and proposal of a measurement scale, Journal of Intellectual Capital, 20(3), 306-334 (2019). Access mode: http://doi.org/10.1108/JIC09-2018-0152

18. K. G. Mal'tsev, A. A. Popel', Problema determinirovannosti sotsial'noy kreativnosti gendernym faktorom: sovremennyye podkhody, Zhenshchina v rossiyskom obshchestve, 4 (69), 77-85 (2013)

19. A. Pūraitè, R. Adamonienè, A. Žemeckè, Sustainable Digitalization in Public Institutions: Challenges for Human Rights, European Journal of Sustainable 
Development, 9 (3), 91 (2020). Access mode: http://doi.org/10.14207/ejsd.2020.v9n3p91

20. J. Kemper, D. Kolkman, Transparent to whom? No algorithmic accountability without a critical audience, Information Communication and Society, 22(4), 1-16 (2018). Access mode: http://doi.org/10.1080/1369118X.2018.1477967

21. K. G. Mal'tsev, A. V. Mal'tseva, L. L. Lomako, Globalizatsiya i vesternizatsiya: gorizonty "otozhdestvleniya" $i$ "razlicheniya", Sotsial'no-politicheskiye nauki, 10(5), 106-114 (2020). Access mode: http://doi.org/10.33693/2223-0092-2020-10-5-106-114

22. I. G. Fikhte, Osnovnyye cherty sovremennoy epokhi, Sochineniya v dvukh tomakh. T. II, 359-618 (1993)

23. Dzh. Agamben, Tsarstvo i slava. K teologicheskoy genealogii ekonomiki i upravleniya (2018)

24. K. Shmitt, Dukhovno-istoricheskoye sostoyaniye sovremennogo parlamentarizma, Ponyatiye politicheskogo, 93-170 (2016)

25. K. Shmitt, Gosudarstvo: Pravo i politika (2013)

26. K. G. Mal'tsev, A. V. Mal'tseva, Biopoliticheskoye proizvodstvo zhizni $i$ «novaya voyna»: opyt filosofskogo istolkovaniya, Intellekt. Innovatsii. Investitsii, 4, 86-94 (2021). Access mode: http://doi.org/10.25198/2077-7175-2021-4-86 